\title{
Perceived Parenting and Basic Need Satisfaction among Portuguese Adolescents
}

\author{
Pedro Cordeiro' ${ }^{1}$, Maria Paula Paixão ${ }^{1}$ and Willy Lens ${ }^{2}$ \\ 1 Universidade de Coimbra (Portugal) \\ 2 University of Leuven (Belgium)
}

\begin{abstract}
We examined the psychometric properties of the Parenting Questionnaire in a sample of Portuguese high school students. Two measurement models were specified. Model $1_{\mathrm{m}, \mathrm{f}}$ specifies a bi-dimensional structure of parental need-support and behavioral control. Model $2_{\mathrm{m}, \mathrm{f}}$ proposes a tripartite structure of parental need-support, psychological control and behavioral control. Model $2_{\mathrm{m}, \mathrm{f}}$ best-fitted the data, being also supported in terms of convergent, discriminant validity. Regression results found the unique effect of autonomy-support $\left(\mathrm{M} 2_{\mathrm{mr}}, b=.25 p<.001 ; \mathrm{M}_{\mathrm{fr}}, b=.14 p<.01\right)$, responsiveness-warmth (Model $2 \mathrm{mr}, b=.19, p<.001$; Model $2_{\mathrm{fr}}, b=.13 p<.05$ ) and behavior control on basic needsatisfaction (Model $2 \mathrm{mr}: b=.14 p<.05$ ), but a non-significant effect of psychological control on need-frustration $(p>.05)$. Notably, psychological control predicted low need-satisfaction $\left(\mathrm{M} 22_{\mathrm{mr}}: b=-.10\right)$ and moderated of the positive effect of parental need-support on need-satisfaction, $\mathrm{M} 2 \mathrm{mr}_{\mathrm{mr}} \mathrm{F}(3,367)=11.62, p<.001$. Psychological control and need-support also moderated the positive effect of behavior control on competence satisfaction, with parental need-support amplifying this effect and psychological control buffering it. Overall the findings support the substantive distinction between the parenting dimensions, suggesting that need-satisfaction is enhanced by need-supportive and behavioural control and undermined by psychological control.
\end{abstract}

Received 12 December 2013; Revised 8 January 2015; Accepted 2 March 2015

Keywords: parenting, need satisfaction, adolescents, Portugal.

For many decades the dimensional and typological approaches to parenting have mapped out the key components of parenting and explored their relations to predict unique variance using developmental criteria (Bean, Barber, \& Crane, 2006).

In general, both approaches essentially agreed that the quality of parent-child interactions would be adequately captured in a set of three interrelated dimensions, featuring parental support, behavior control and psychological control (Barber \& Xia, 2013).

Parental support covers the parental attitudes of autonomy-support, that promote self-initiation, freedom of expression and intrinsic motivation (Barber, 1996; Deci \& Ryan, 1985), and responsiveness-warmth, related to the affective and involved ways through which parents interact with their children (Barber, Stolz, \& Olsen, 1995; Soenens, Duriez, Vansteenkiste, \& Goossens, 2007). Behavior control features the positive and active parental efforts intended to regulate or provide structure for the children's behavior (Barber, 1996; Steinberg, 1990, 2005). Finally, psychological control characterizes

Correspondence concerning this article should be addressed to Pedro Miguel Gomes Cordeiro. Faculdade de Psicologia e de Ciências da Educação da Universidade de Coimbra. Rua do Colégio Novo. 3000-115. Coimbra (Portugal). Phone: +351-966664542.

E-mail: pedrcordeiro@gmail.com

This research was fully supported by the first author's scholarship from the Foundation for Science and Technology - Portugal. the manipulative and autonomy-inhibiting parental attitudes of guilt-induction, shaming, love withdrawal and invalidation of the child's perspective that intrudes on the child's individuality (Barber, 1996; 2002; Barber \& Harmon, 2002).

However, the broad consensus gained in the identification of the parenting dimensions contrasts with the diverse modeling approaches that have been used to examine their dimensionality. On the one hand, the research conducted on the dimensional approach to parenting (e.g., Gray \& Steinberg, 1999) modeled one or two of the three parental dimensions at a time, at the risk of exaggerating or misinterpreting the effect of specific dimensions, when other dimensions were not considered. On the other hand, the research based on the typological approach to parenting (e.g., Baumrind, 1966) usually aggregated specific dimensions to form different parenting styles or clusters, making it impossible to isolate and to examine the unique or joint effects of specific parental dimensions on motivational outcomes (Bean et al., 2006).

The modeling diversity has subsidized the persistence of ambiguities at both the conceptual and operational levels (Bean et al., 2006). For instance, despite the broad consensus obtained for the linear positive effects of supportive/nurturing parenting based on developmental criteria (for a review see Ryan \& La Guardia, 2000), there is still some confusion regarding 
the linear, piecewise or even non-linear effects of behavior control on motivational outcomes (Soenens \& Byers, 2012; Soenens \& Vansteenkiste, 2010; for a review, see Barber et al., 2005). Likewise, despite the consistent support obtained for the effects of parental psychological control on maladjustment (e.g., Barber, 1996; Barber et al., 2005; Wang, Pomerantz, \& Chen, 2007), it is still not absolutely clear how other dimensions of parental psychological control relate to ill-being and maladjustment (e.g., rejection, chaos; for a review, see Soenens \& Vansteenkiste, 2010).

To this ambiguous findings contributed the fact that the parenting dimensions/typologies have been identified from predominantly empirically-driven approaches (e.g., psychological control; Schaefer, 1965). Although the inductive approach yielded numerous important insights in the meaning and consequences of parenting, the research on parenting would benefit from top-down, or relatively more theory driven approaches (Steinberg, 2005) to bring a more conceptual and operational unity to the findings.

\section{A Self-Determination Theory Perspective on Parenting}

Self-Determination Theory (SDT; Deci \& Ryan, 1985, 2000) provides a comprehensive account of the dynamics and mechanisms through which parenting impacts the psychosocial development of children (Skinner, Johnson, \& Snyder, 2005). SDT posits that the effects of parenting on development are mediated by the satisfaction of the basic psychological needs of autonomy, competence and relatedness (Deci \& Ryan, 1985; Ryan, 1993; Ryan, 1995). Autonomy is the need to experience self-endorsement, volition and choice in the initiation and regulation of personal actions (Deci \& Ryan, 1985,), competence is the need to be effective in goal attainment and environmental interactions, in the process of mastering various challenges (Deci \& Ryan, 1985; Schunk \& Zimmerman, 2007) and relatedness, the desire to feel emotionally connected to others within warm, supportive and caring interpersonal relationships (Baumeister \& Leary, 1995; Ryan, 1995). For SDT, the basic psychological needs are innate and universal psychological mechanisms that energize and regulate goal-directed behavior towards psychological development, integrity, and well-being, in a continual dialectical interplay between the organismic tendency towards growth and psychological development, and the degree to which parents, as primary socialization agents, support or thwart the satisfaction of needs (Deci \& Ryan, 1985, 2000).

Parents promote basic need-satisfaction when they support the children's autonomy in a volitional way (Autonomy-support-PVF; Deci \& Ryan, 1985, 2000), when they interact with their children in a responsive and warm manner (Responsiveness-warmth; Barber, 1996;
Deci \& Ryan, 1985; Ryan, 1993; Soenens et al., 2007) or when they provide structure for their behavior (behaviour control; Barber, 1996; Barber, Olson, \& Shaggle, 1994; Grolnick \& Ryan, 1989). Autonomy-supportive parents provide an optimal amount of choice for their actions, or an adequate rationale when choice is constrained, and refrain from using insidious, manipulative and invasive practices (Deci \& Ryan, 1985, 2000). Responsive-warmth parents easily attune and empathize with their children's experiences and feelings, and interact with their children in involved, affectionate and accepting ways (Soenens, Vansteenkiste, Duriez et al., 2006). Finally, behaviorally controlling parents make positive efforts to regulate and structure the child's behavior (e.g., manners, study activities, and involvement with peers) through the provision of clear expectations/rules and active monitoring efforts (e.g., Barber, 2002).

Parents may also actively thwart or block the satisfaction of psychological needs (parental psychological control; Deci \& Ryan, 2000, Vansteenkiste \& Ryan, 2013), when they use psychological control to regulate the psychological experiences and behavior of their children (Soenens \& Vansteenkiste, 2010). For SDT, psychological control characterizes the internally controlling and manipulative techniques of guilt-induction, shaming and love withdrawal used to coerce the children to change their psychological (thoughts, feelings) and behavioral experiences according to their expectations (Soenens \& Vansteenkiste, 2010).

The research based on SDT has consistently demonstrated that parental need-support and behavior control promote growth, intrinsic motivation and psychological well-being via the experience of basic need-satisfaction (Deci \& Ryan, 1985; Ryan \& Deci, 2000; Vansteenkiste \& Ryan, 2013), whereas parental psychological control relates to maladjustment, ill-being and psychopathology, through the experience of basic need-frustration (Barber, 1996; Bartholomew, Ntoumanis, Ryan, \& ThøgersenNtoumani, 2011; Cordeiro, Paixão, Lens, \& Sheldon, 2015; Soenens et al., 2008; Soenens, Vansteenkiste, Luyten, Duriez, \& Goossens., 2005; Verstuyf, Vansteenkiste, Soenens, Boone, \& Mouratidis, 2013) ${ }^{1}$.

Although generally accepted, most findings were obtained from narrow-scoped factor analysis (for an exception, Skinner et al., 2005), making it difficult to establish firm conclusions about the validity of the parental dimensions assessed and the precise ways through which the parenting dimensions relate (e.g., interact) to predict the developmental outcomes (Barber \& Xia, 2013).

\footnotetext{
${ }^{1}$ For construct clarification, need-satisfaction and need-frustration are the psychological processes that result from a history of parental support or thwarting of basic needs over time (Vansteenkiste \& Ryan, 2013).
} 
The present study

In this study we will examine the factor structure of the Parenting Questionnaire Scales (PQS; Soenens, Vansteenkiste, Duriez et al., 2006), to provide evidence for their and construct validity. This aim is of particular importance, for two reasons. From a conceptual point of view we are among the few to use of a top-down approach, and particularly the Self-Determination Theory, to integrate the findings (See et al., 2005 for a similar approach). Methodologically we offer, for the first time, a broad factor-analysis of the full set of the scales.

As a first goal we examined the factor structure of the PQS in two Models. The first - Model $1_{\mathrm{m}, \mathrm{f}}$ (m for mothers; f for fathers), tested the PQS in a two-factor structure. The first factor measures parental need-support (Duriez, Soenens, \& Vansteenkiste, 2007) in a composite score combining the scales of autonomy-support (POPS; Grolnick, Ryan, \& Deci, 1991), responsiveness-warmth (CRPBI; Schaefer, 1965), and (a lack of) psychological control (YSR; Barber, 1996). The second factor assesses behavioral control in a composite score that aggregates the measures of expectations for behavior and monitoring of behavior (PRS - YSR; Barber, 2002). The second Model $2 \mathrm{~m}$,f tested the PQS in an alternative three-factor structure. The first factor measures parental needsupport, in a composite score that aggregates the scales of autonomy-support and responsiveness-warmth. The second factor assesses behavior control in a composite score that combines the measures of expectations for behavior and monitoring of behavior. The third factor measures parental psychological control from the psychological control scale. In both Model $1_{\mathrm{m}, \mathrm{f}}$ and Model $2 \mathrm{~m}, \mathrm{f}$ the dimensions of behavior control and psychological control are measured as two separate factors, in line with the SDT argument that behavior control, deals with "what" parents do to regulate their children's behavior outcomes, whereas autonomy-support refers to "how" parents implement it (Soenens \& Vansteenkiste, 2010). However, Model $1_{\mathrm{m}, \mathrm{f}}$ and Model $2_{\mathrm{m}, \mathrm{f}}$ diverge in the way as the Psychological Control items are codified. In fact, whereas in Model $1_{\mathrm{m}, \mathrm{f}}$ the psychological control items were reverse-scored to measure parental needsupport (see Miklikowska, Duriez, \& Soenens, 2011 for a similar approach), in Model $2 \mathrm{~m}, \mathrm{f}$ they are direct-scored to assess psychological control. We expect a better fit for Model $2_{\mathrm{m}, \mathrm{f}}$, based on the SDT premise that the parental need-support and the psychological control dimensions of parenting have different substantive interpretations and effects (e.g., Bartholomew et al., 2011; Sheldon, Abad, \& Hinsch, 2011; Vansteenkiste \& Ryan, 2013).

In a second goal we examined the criterion-related validity of the best-fitting model, according to five
SDT-based hypotheses (Vansteenkiste \& Ryan, 2013). In a first hypothesis we expect the primary effects of parental need-support and of behavior control on needsatisfaction and of parental psychological control on need-frustration (Hypothesis 1). Second, we expect the cross-lagged effects of parental need-support on need-frustration and of psychological control on needsatisfaction (Hypothesis 2). Third, we hypothesize that parental need-support and psychological control moderate the positive effect of behavior control on needsatisfaction (Hypothesis 3a), that parental need-support moderates the positive effect of psychological control on need-frustration (Hypothesis 3b), and also that psychological control moderates the positive effect of parental need-support on need-satisfaction (Hypothesis 3c). We intended to verify whether our hypothesis are valid for the developmental stage of adolescence, the reason why we used a sample of high school students.

\section{Method}

\section{Participants}

We sampled 371 Portuguese high school students (grade 10: $n=101$ [27.2\%], grade 11: $n=148$ [39.9\%], grade $12 n=122$ [32.9\%]), of both sexes (Male: $n=171$ [46.1\%], female $n=200$ [53.9\%]), aged between 16 and 23 years old $(M=18 ; S D=1.309)^{2}$. Students attended scientific-humanistic ( $n=153[41.2 \%])$ and technicalvocational courses $(n=218[58.8 \%])$ in public $(n=182$ [49.1\%]) and private schools $(n=189$ [50.9\%]). Passive informed consent was obtained from the parents of younger students. All subjects volunteered for the study and completed the questionnaires without missing responses. No credits were granted for participating in the study.

\section{Procedure}

Prior to data collection the researchers obtained the mandatory permissions from the General Directorate for Innovation and Curricular Development and from the school principals. Next, the questionnaires were group-administered in the classroom, during regular class hours. The primary researcher read aloud the instructions of the PQS "The following statements deal with the way in which your father/mother behaves towards you; indicate to what degree you agree with these statements by circling one of the numbers", and of the Balanced Measure of Psychological Need Scale (Sheldon \& Hilpert, 2012) "Please read each of the following statements carefully, thinking about how true it

\footnotetext{
${ }^{2}$ In the Portuguese education system, the secondary education level comprises the $10^{\text {th }}, 11^{\text {th }}$ and $12^{\text {th }}$ school years. The age of students ranges from 17 and 23 years old, with older students commonly having an history of academic failure.
} 
is for you". Aspects such as the voluntary participation and confidentiality of the data were secured in the instructions. Students took around 20 minutes to complete the questionnaires.

\section{Measures}

\section{Perceived Parenting}

The 76-item Parenting Questionnaire Scales was used to measure perceived parenting. The PQS is not a questionnaire per se, but a composite instrument composed of five scales: the 7-item autonomy-support scale, retrieved from the Perceptions of Parents Scales (POPS; Grolnick et al., 1991, e.g., "My mother/father is usually willing to consider things from my point of view), the 7-item responsiveness-warmth scale, included in the Child Report of Parent Behavior Inventory (CRPBI; Schaefer, 1965, e.g., "My father/mother makes me feel better after I discuss my worries with him/her"), the 8-item psychological control scale, integrated in the Youth Self-Report (PCS-YSR; Barber, 1996; e.g., "My mother/father changes the subject whenever I have something to say), the 8-item expectations for behavior scale (e.g., "My mother/father believes that children should not be able to do anything they want") and the 8-item Monitoring of Behavior Scale (e.g., "My mother/father asks me questions about how I am behaving outside the home"), included in the Parental Regulation Scale - Youth Self-Report (PRS-YSR; Barber, 2002). The PQS was rated separately for mothers $(N=38)$ and fathers $(N=38)$, on a 6-point Likert-type scale, ranging from 1 (Totally Agree) to 5 (Totally disagree). The Cronbach's alphas reported for maternal and paternal ratings ranged from .67 to .70 for autonomysupport (Grolnick et al., 1991), .88 to .92 for responsiveness-warmth (Soenens et al., 2005), .82 to .80 for psychological control (Barber, 1996), and .83 to .82 for behavior control (Soenens, Vansteenkiste, Luyckx et al., 2006).

\section{Translation}

We translated the Parenting Questionnaire Scales into Portuguese using the back-translation procedure (Hambleton, 2001). A professional interpreter collaborating with the fluent English-speaking researchers translated the PQS from English to Portuguese. Next, an independent interpreter translated the scales back into English. Both original and back-translated versions were checked for accuracy, and the discrepancies resolved through consensus. The readability and unambiguous understanding of the PQS items was further examined in a pilot study ( $N=11$ Portuguese high school students), resulting in the wording and syntax modifications of three items (items 5, 29, and 14).

\section{Basic Psychological needs}

We used the Portuguese adaptation of the Balanced Measure of Psychological Needs Scale (BMPN; Sheldon \& Hilpert, 2012; Portuguese version: Cordeiro et al., 2015). The BMPN is an 18-item self-report questionnaire measuring basic psychological need-satisfaction and need-frustration in six three-item scales. Three positivelyworded scales measure the satisfaction of autonomy ("My choices are based on my true interests and values"), competence ("I am successful at completing difficult tasks and projects") and relatedness needs ("I feel a sense of contact with people who care for me, and whom I care for"). In addition, three negativelyworded scales measure the frustration of autonomy (e.g. "I do things against my will"), competence ("I do stupid things that make me feel incompetent"), and relatedness needs ("I feel unappreciated by one or more important people"). All items are rated on a 5-point Likert scale, ranging from $1=$ no agreement to $5=$ much agreement. The internal consistency of the scales reported for the Portuguese version of the BMPN was of .84, .79 , and .82 for autonomy, competence, and relatedness satisfaction, and of $.85, .82$, and .77 for autonomy, competence, and relatedness frustration, respectively. In this study, we modeled the six BMPN scales in a structure of two second-order factors measuring the general experience of basic need-satisfaction and of basic need-frustration $(\alpha=.82, .85$, respectively; Cordeiro et al., 2015).

\section{Plan of analysis}

We examined the internal structure of the Parenting Questionnaire Scales using AMOS (V.20, SPSS Inc, Chicago, IL). In the first step we computed successive confirmatory factor analyses (CFA, Byrne, 2010) with ML estimation, to test the fit of Model $1_{\mathrm{m}, \mathrm{f}}$ and Model $2_{\mathrm{m}, \mathrm{f}}$ to the PQS data. Goodness-of-fit was judged from multiple fit indices, namely the Chi square $\left(\chi^{2}\right)$ statistics, the Standardized Root Mean Square Residual (RMR), the Comparative Fit Index (CFI) and the Root Mean Squared Error of Approximation (RMSEA). The combined cut-off values of .09 for SRMR, .06 for RMSEA, $p$ (RMSEA $\leq 0.05$ ) and .90 , or above, for CFI, showed an acceptable fit (Hu \& Bentler, 1999). The lowest values obtained in the Akaike's Information Criteria (AIC; Byrne, 2010) indicated the preferred model. Further, we used the Standardized Factor Loadings and the Modification Indices to modify the best-fitting model. We excluded from further analysis all items presenting poor factor loadings $\left(\lambda i \geq 0.5 ; \lambda^{2} i j \geq\right.$ 0.25 ; Maroco, 2010) or high cross-loadings ( $\mathrm{MI}>9$ ). In the second step we performed an Exploratory Factor Analyses (EFA; McIver \& Carmines, 1981), in principal components (PCA), and varimax orthogonal rotation 
to the data, in order to corroborate the best-fitting model found in CFA. In the third step we used the STATS Tool Package (Gaskin, 2012) to examine the Convergent ( $A V E i \geq 0.5$; Fornell \& Larcker, 1981) and Discriminant Validities (MSV < AVE; ASV < AVE; Fornell \& Larcker, 1981) of the factors. Finally, in the fourth step we performed successive Linear Regression Analyses to examine the main/cross-lagged effects between the variables. In addition, we used hierarquical regression analyses to examine for possible moderation effects. In the hierarquical regression procedure we examined the slope of the relationship between the predictors and the outcome variables, at low (one SD below the mean) and high (one SD above the mean) levels of moderator.

\section{Preliminary Results}

\section{Confirmatory Factor Analysis}

Table 1 summarizes the estimates of goodness-of-fit and model quality of Model $1_{\mathrm{m}, \mathrm{f}}$ and Model $2_{\mathrm{m}, \mathrm{f}}$. Figure 1 provides a graphical representation of the respecified models. Initial CFAs yield an important misfit for the two models tested, nevertheless favoring the Model $2_{\mathrm{m}, \mathrm{f}}$ across all the fit indices considered. We modified the Model $2 \mathrm{~m}$,f. to improved goodnessof-fit. Firstly, we dropped from further analyses 14 items with high cross-loadings on non-intended factors (MI > 9; Maroco, 2010) and 12 items with poor loadings on the respective factor $\left(\lambda_{i j} \geq 0.5\right)$. Secondly, we aggregated several scales presenting high empirical correlations (Maroco, 2010). Specifically, we combined the scales of expectations of behavior and monitoring of behavior (Model $2 \mathrm{~m} r=.89, p<$ .001 ; Model $2 \mathrm{f}, r=.84, p<.001$ ) to measure behavior control and the scales autonomy-support and responsiveness-warmth $\left(\right.$ Model $_{2 \mathrm{~m}}, r=.85, p<.001$; Model $\left.2_{\mathrm{f}}, r=.95, p<.001\right)$ to measure parental needsupport. In a final procedure we correlated the measurement errors of the items $1 ; 31,31 ; 20,5 ; 20$. The resulting respecified Model (now designated Model $2 \mathrm{mr}, \mathrm{fr})$ is organized in a solution of 15 items and three factors, measuring parental need-support, behavior control and parental psychological control. Subsequent CFA results show the improved fit of Model $2 \mathrm{mr}$,fr. In addition, the lowest AIC scores indicate that Model $2 \mathrm{mr}$,fr is preferred to interpret the factorial structure of the PQS.

\section{Exploratory factor analysis (EFA)}

Table 2 presents the reliability estimates for the PQS items and scales. The Exploratory Factor Analyses extracted a solution of three components with eigenvalues greater than 1, explaining 46, 20\% (Model $2 \mathrm{mr}$ ) and 57, 28\% (Model 2 fr) of the total variance of the data, respectively (Tiensley \& Tiensley, 1987). The three scales demonstrated good internal consistency, for both the maternal and paternal ratings, with all items loading significantly on the intended factor $\left(\lambda_{i j} \geq .50\right.$; $\left.\lambda^{2}{ }_{i j} \geq .25\right)$. Together, the EFA results corroborate the 3-factor solution found in CFA.

\section{Correlations}

Table 3 summarizes the means, standard deviations and correlations obtained for the three factors. The examination of the correlation matrix shows a modest negative correlation (VIF < 5) between parental needsupport and psychological control (Model $2 \mathrm{mr} r=-.34$, $p<.001$ Model $2_{\mathrm{fr}} r=-.43, p<.001$ ), suggesting that the factors measure two distinct parental dimensions. In addition, behavior control does not correlate to either parental need-support (Model $2{ }_{\mathrm{mr}} r=.19, p=.72$ ) nor to psychological control (Model $2 \mathrm{mr} r=.09, p=.79 ; \mathrm{M} 2 \mathrm{fr}$ $r=-.07, p=.79)$, thus suggesting that behavior control is orthogonal to both the supportive and thwarting dimensions of parenting (see Soenens \& Vansteenkiste, 2010 for a discussion). Remarkably, the high correlation observed between the dimensions of paternal behavior control and need-support Model $2_{\mathrm{fr}}(r=.56$, $p<.001)$ suggests that, for the Portuguese context, the paternal enforcement of behavior control is more positively-valued as an expression of need-support than the maternal.

Table 1. Global Fit Indices for the Hypothesized Models

\begin{tabular}{lrlllllrr}
\hline Model & \multicolumn{1}{l}{$\chi^{2}$} & $d f$ & $p$-value & $\chi^{2} / d f$ & CFI & RMSEA & RMR & AIC \\
\hline Model $1_{\mathrm{m}}$ & 2981.42 & 66 & $p<.001$ & 4.49 & .56 & .10 & .18 & 3135.42 \\
Model $2_{\mathrm{m}}$ & 2796.01 & 66 & $p<.001$ & 4.22 & .56 & .09 & .18 & 2954.09 \\
Model $2_{\mathrm{mr}}$ & 198.76 & 79 & $p<.001$ & 2.52 & .93 & .06 & .10 & 280.76 \\
Model $1_{\mathrm{f}}$ & 3098.66 & 66 & $p<.001$ & 4.67 & .64 & .10 & .19 & 3252.66 \\
Model $2_{\mathrm{f}}$ & 2635.70 & 66 & $p<.001$ & 3.98 & .71 & .09 & .18 & 2793.70 \\
Model $2_{\mathrm{fr}}$ & 187.50 & 78 & $p<.001$ & 2.40 & .95 & .06 & .07 & 271.50 \\
\hline
\end{tabular}

Note: $\mathrm{X} 2$ qui-square; $\mathrm{CFI}$ = comparative fit index; RMSEA = root-mean-square error of approximation; RMR = root-mean-square residual; $\mathrm{AIC}=$ Akaike information criterion 


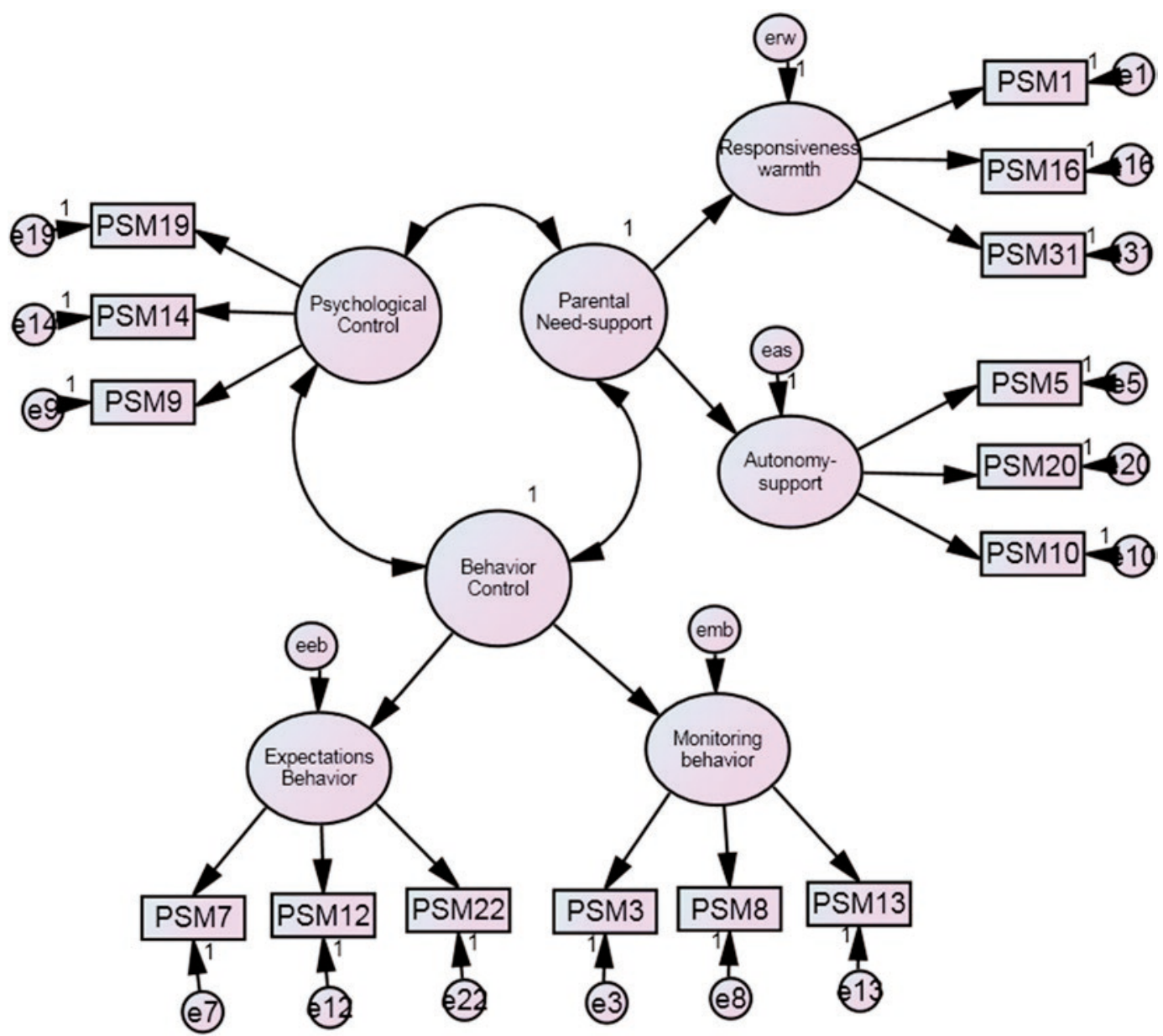

Figure 1. Standardized estimates for M2 (maternal and paternal).

Model 2

\section{Validity}

Table 4 summarizes the validity estimates for the three PQS factors. We found Convergent validity (CV) for all the questionnaire factors except for the measures of maternal need-support and behavior control. The CV threats found are explained by the modest correlations verified between the dimensions of monitoring of behavior and autonomy-support in the respective second-order factors of need-support and behavior control. The additional CV threat detected for the factor paternal psychological control is justified by the modest loadings of the items in the factor. No threats to the discriminant validity of the scales were verified, thus suggesting the divergent validity of the three factors.

\section{Primary results}

Table 5 portrays the results of linear regression analyses. We examined the effects of behavior control, parental need-support and psychological control on the adolescents' experience of basic need-satisfaction and of need-frustration (Vansteenkiste \& Ryan, 2013).

\section{Main effects}

The results support the main effects of parental needsupport on general need-satisfaction. This effect was verified for both the first-order dimensions of autonomy-support, Model $2 \mathrm{mr}, \beta=.25, t(1,369)=4.88$, $p<.001$; Model $2_{\mathrm{fr},} \beta=.14, t(1,369)=2.78, p<.01$, and responsiveness-warmth: Model $2 \mathrm{mr}, \beta=.19, t(1,369)=$ $3.76, p<.001$; Model $2_{\text {fr }} \beta=.13, t(1,369)=2.59, p<.05$. However, when autonomy-support and responsivenesswarmth were entered together in a hierarchical regression procedure, the effect of responsiveness-warmth was reduced to non-significance, Model $2 \mathrm{mr}, \beta=.05$, $t(1,369)=.66, p=.52$; Model $2_{\mathrm{fr}}, \beta=-.01, t(1,369)=$ $-.06, p=.95$, suggesting suppression effects. The results also support the main effect of behavior control on basic need-satisfaction, Model $2 \mathrm{mr}: \beta=.14, t(1,369)=2,80$, $p<.05$; Model $2_{\mathrm{fr}}: \beta=.08, t(1,369)=1,78, p=.08$, and, particularly, on competence satisfaction: Model $2 \mathrm{mr}: \beta=.16$ 
Table 2. P-BMPN Reliability and Validity Estimates for the Reduced Solution of Portuguese version of the Parenting Questionnaire Items and Scales

\begin{tabular}{|c|c|c|c|c|}
\hline \multirow[b]{2}{*}{ Item } & \multicolumn{3}{|c|}{$\lambda_{i j} \geq 0.5(\mathrm{CI} 95 \%)$} & \multirow[t]{2}{*}{$\lambda_{i j}{ }^{2}(\geq 0.25)$} \\
\hline & F1 & F2 & F3 & \\
\hline 9. My mot her/father changes the subject whenever I have something to say & .82 & & & .67 \\
\hline 19. My mother/father blames me for other family members' problems & $.81(.81)$ & & & $.66(.66)$ \\
\hline 14. My mother/father often interrupts me & $.83(.81)$ & & & $.69(.66)$ \\
\hline 38. If I have hurt his/her feelings, my mother/father stops talking to me until I please him/her again & $(.79)$ & & & $(.62)$ \\
\hline 29. My mother/father is less friendly with me if I do not see things / her way & $(.57)$ & & & $(.32)$ \\
\hline 3. My mother/father asks me questions about how I am behaving outside the home & & $.59(.60)$ & & $.34(.36)$ \\
\hline 13. My mother/father watches to make sure I behave appropriately & & $.71(.76)$ & & $.50(.58)$ \\
\hline 22. My mother/father believes parents have the right to set rules and regulations for how children should behave & & $.63(.66)$ & & $.40(.44)$ \\
\hline 2. My mother/father has clear expectations for how I should behave in and outside the home & & $(.61)$ & & $(.37)$ \\
\hline 37. My mother/father checks on me in reasonable ways to see if I am behaving like he/she wants me to & & $(.63)$ & & $(.40)$ \\
\hline 17. My mother/father wants me to learn to follow rules and regulations in and outside of the home & & $(.82)$ & & $(.67)$ \\
\hline 7. My mother/father requires that I behave in certain ways & & .69 & & .48 \\
\hline 12. My mother/father believes that children should not be able to do anything they want & & .56 & & .31 \\
\hline 8. My mother/father reminds me of the rules he/she has set for me & & .76 & & .58 \\
\hline 1. My mother/father makes me feel better after talking over my worries with him/her & & & $.73(.65)$ & $.53(.42)$ \\
\hline 16. My mother/father cheers me up when I am sad & & & $.75(.75)$ & $.56(.56)$ \\
\hline 31. My mother/father enjoys doing things with me & & & $.69(.73)$ & $.48(.53)$ \\
\hline 5. My mother/father listens to my opinion or perspective when I've got a problem & & & $.73(.75)$ & $.53(.56)$ \\
\hline 10. My mother/father is usually willing to consider things from my point of view & & & $.81(.73)$ & $.66(.53)$ \\
\hline 20. My mother/father allows me to decide things for myself & & & $.67(.67)$ & $.45(.45)$ \\
\hline Cronbach's Alpha & $.80(.71)$ & $.74(.81)$ & $.84(.87)$ & \\
\hline
\end{tabular}

Note 1: $\lambda_{i j}=$ standardized factor score weights; $\lambda_{i j}{ }^{2}$ individual-item reliability.

Note 2: Values between brackets correspond to Model 2 fr estimates 
Table 3. Response rate (N), Means, Standard Deviations (SD), and Correlations of the Study Variables

\begin{tabular}{|c|c|c|c|c|c|c|c|c|c|c|c|c|c|c|}
\hline Factors & $N$ & $M$ & $S D$ & 1 & 2 & 3 & 4 & 5 & 6 & 7 & 8 & 9 & 10 & 11 \\
\hline 1.PNS & 371 & $3.75(3.45)$ & $.87(.93)$ & 1 & $\left(-.43^{* *}\right)$ & $\left(.56^{* *}\right)$ & $\left(.15^{* *}\right)$ & $(.10)$ & $\left(.15^{* *}\right)$ & $(-.00)$ & $(-.03)$ & $(-.05)$ & $\left(.17^{* *}\right)$ & $(-.04)$ \\
\hline 2.PC & 371 & $2.42(2.29)$ & $1.11(.89)$ & $-.34^{* *}$ & 1 & $(-.07)$ & $(-.06)$ & $(-.04)$ & $(-.07)$ & $(.01)$ & (.05) & $(.01)$ & $(-.07)$ & $(.03)$ \\
\hline 3. BC & 371 & $3.73(3.57)$ & $.70(.78)$ & .02 & .091 & 1 & $(.05)$ & $(.08)$ & $(.09)$ & $(.02)$ & $(-.03)$ & $(-.09)$ & $(.08)$ & $(-.05)$ \\
\hline 4. AS & 371 & 4.05 & .68 & $.20^{* *}$ & -.08 & .03 & 1 & $\left(44^{* *}\right)$ & $\left(.36^{* *}\right)$ & $(-.07)$ & $(-.06)$ & $\left(-.19^{* *}\right)$ & $\left(.79^{* *}\right)$ & $\left(-.14^{* *}\right)$ \\
\hline 5. CS & 371 & 3.82 & .67 & $.15^{* *}$ & -.07 & $.16^{* *}$ & $.44^{* *}$ & 1 & $\left(.34^{* *}\right)$ & $(-.00)$ & $(-.10)$ & $\left(-.11^{*}\right)$ & $\left..77^{* *}\right)$ & $(-.09)$ \\
\hline 6. RS & 371 & 4.26 & .67 & $.20^{* *}$ & $-.16^{* *}$ & -.02 & $.36^{* *}$ & $.34^{* *}$ & 1 & $(-.02)$ & $(-.07)$ & $\left(-.17^{* *}\right)$ & $\left(.74^{* *}\right)$ & $\left(-.11^{*}\right)$ \\
\hline 7. $\mathrm{AF}$ & 371 & 3.20 & .89 & -.05 & .04 & -.01 & -.07 & -.00 & -.02 & 1 & $\left(.51^{* *}\right)$ & $\left(.47^{* *}\right)$ & $(-.04)$ & $\left(.80^{* *}\right)$ \\
\hline 8. CF & 371 & 2.66 & 1.06 & -.09 & .03 & -.04 & -.06 & -.10 & -.07 & $.51^{* *}$ & 1 & $\left(.56^{* *}\right)$ & $(-.10)$ & $\left(.80^{* *}\right)$ \\
\hline 9. RF & 371 & 2.40 & 1.05 & -.10 & .01 & -.03 & $-.19^{* *}$ & $-.11^{*}$ & $-.17^{* *}$ & $.47^{* *}$ & $.557^{* *}$ & 1 & $\left(-.20^{* *}\right)$ & $\left(.85^{* *}\right)$ \\
\hline 10. NS & 371 & 4.04 & .515 & $.24^{* *}$ & $-.14^{* *}$ & $.14^{*}$ & $.79^{* *}$ & $.77^{* *}$ & $.74^{* *}$ & -.04 & -.099 & $-.20^{* *}$ & 1 & $\left(-.15^{* *}\right)$ \\
\hline 11. NF & 371 & 2.77 & .814 & -.10 & .03 & -.03 & $-.14^{* *}$ & -.09 & $-.11^{*}$ & $.80^{* *}$ & $.804^{* *}$ & $.85^{* *}$ & $-.15^{* *}$ & 1 \\
\hline
\end{tabular}

Note PNS = Parental Need-support $;$ PPC $=$ Parental Psychological Control; BC = Behaviour Control; $\mathrm{AF}=$ Autonomy Satisfaction; $\mathrm{CF}=\mathrm{Competence} \mathrm{Satisfaction} ; \mathrm{RS}=\mathrm{Relatedness}$ Satisfaction; AF = Autonomy Frustration; $\mathrm{CF}=$ Competence Frustration; RF = Relatedness Frustration; NS = Need-satisfaction; NF = Need-frustration. Values between brackets correspond to Model $2 \mathrm{f}_{\mathrm{r}}$ estimate.

${ }^{*} p<.05^{* *} p<.01$. 
Table 4. Factor Correlation, Reliability and Validity Estimates for the Models Tested

\begin{tabular}{|c|c|c|c|c|c|c|c|}
\hline & \multirow{2}{*}{$\frac{\text { Composed reliability }}{\mathrm{CR}}$} & \multirow{2}{*}{$\frac{\text { Convergent validity }}{\mathrm{AVE}}$} & \multicolumn{2}{|c|}{$\begin{array}{l}\text { Discriminant } \\
\text { Validity }\end{array}$} & \multicolumn{3}{|c|}{$\begin{array}{l}\text { Correlation of latent } \\
\text { constructs }\end{array}$} \\
\hline & & & MSV & ASV & PNS & PNT & $\mathrm{BC}$ \\
\hline \multicolumn{8}{|c|}{ Model 2mr } \\
\hline F1. PNS & 0.80 & 0.58 & 0.10 & 0.06 & 0.76 & & \\
\hline F2. PC & 1.06 & 1.11 & 0.10 & 0.05 & -0.32 & 1.05 & \\
\hline F3. BC & 2.05 & 2.98 & 0.02 & 0.01 & 0.15 & 0.03 & 1.73 \\
\hline \multicolumn{8}{|c|}{ Model 2fr } \\
\hline F1. PNS & 0.95 & 0.90 & 0.48 & 0.39 & 0.95 & & \\
\hline F2. PC & 0.73 & 0.41 & 0.30 & 0.15 & -0.55 & 0.64 & \\
\hline F3. BC & 0.95 & 0.90 & 0.48 & 0.25 & 0.70 & -0.07 & 0.95 \\
\hline
\end{tabular}

Note: $R^{2}$ = factor square correlations; Convergent validity (AVEi $\left.\geq 0.5\right)$; Composite reliability $(\mathrm{CR} \geq 0.7)$, Discriminant Validity $\left(\mathrm{R}^{2}\right)$ Average Variance Extracted (AVE), Maximum Shared Squared Variance (MSV), and Average Shared Squared Variance (ASV).

Table 5. Regression Analysis Predicting Basic Need-Satisfaction and Need-Frustration

\begin{tabular}{|c|c|c|c|c|c|c|}
\hline \multirow[b]{3}{*}{ Predictor } & \multicolumn{6}{|c|}{ Dependent Variables } \\
\hline & \multicolumn{3}{|c|}{ Mother $\left(\mathrm{M} 2_{\mathrm{mr}}\right)$} & \multicolumn{3}{|c|}{ Father $\left(\mathrm{M} 2_{\mathrm{fr}}\right)$} \\
\hline & $\mathrm{BC}$ & PNS & PC & $\mathrm{BC}$ & PNS & PC \\
\hline Autonomy-satisfaction & .05 & $.20^{* *}$ & -.08 & .05 & $.14^{*}$ & -.06 \\
\hline Competence-satisfaction & $.16^{* *}$ & $.15^{*}$ & -.07 & .05 & $.11^{*}$ & -.04 \\
\hline Relatedness-satisfaction & .02 & $.20^{* *}$ & $-.16^{* *}$ & .09 & $.15^{*}$ & -.07 \\
\hline Autonomy-frustration & -.01 & -.05 & .04 & .02 & -.01 & .01 \\
\hline Competence-frustration & -.04 & -.09 & .03 & -.03 & -.03 & .05 \\
\hline Relatedness-frustration & -.03 & -.06 & .01 & -.09 & -.05 & .01 \\
\hline General Need-Satisfaction & $.14^{*}$ & $.24^{* *}$ & $-.14^{*}$ & .08 & $.17^{* *}$ & -.07 \\
\hline General Need-Frustration & -.03 & -.10 & .03 & -.04 & -.04 & .03 \\
\hline
\end{tabular}

Note: ${ }^{*} p<.05 ; * *<.01$.

$t(1,369)=3,16, p<.01 ;$ Model 2fr: $\beta=.05, t(1,369)=.88$, $p=.38$. However, behavior control was not a significant predictor of need-frustration, Model $2 \mathrm{mr}: \beta=-.03$, $t(1,369)=-.53, p=.60 ;$ Model 2 fr $\beta=-.05, t(1,369)=-.78$, $p=43$. Importantly, against what is predicted by SDT (Vansteenkiste \& Ryan, 2013), the findings did not provide support for the main effect of psychological control on need-frustration, Model $2_{\mathrm{mr}} \beta=.03, t(1.369)=$ $.56, p=.57$; Model $2_{\text {fr }} \beta=.03, t(1.369)=.52, p=.60$. Overall, the results provided partial support for the first hypothesis of our study.

\section{Cross-lagged effects}

We further examined the predicted cross-lagged effects between the variables (Vansteenkiste \& Ryan, 2013). We found that maternal psychological control had a significant negative effect on basic needsatisfaction, Model $2 \mathrm{mr}: \beta=-.14, t(1,369)=-1,36$, $p<.05)$, while parental need-support does not have a significant effect on need-frustration, Model $2 \mathrm{mr}$ : $\beta=-.10, t(1,369)=-.61, p>.05$, Model $2 \mathrm{fr}: \beta=.04$, $t(1,369)=-1.94, p>.05$.

\section{Moderation effects}

In subsequent analyses we explored the existence of possible moderation effects between the variables. The results of hierarquical regression analysis showed that both parental need-support and psychological control moderated the positive effect of behavior control on general need-satisfaction, with parental need-support amplifying this effect and psychological control buffering it. We also found that maternal psychological control buffered the positive effect of need-support on need-satisfaction, Model $2_{\mathrm{mr}}: F(3,367)=11.62, p<.001$; Model 2 fr: $F(3,367)=3.49, p<.05)$. The asymmetrical cross-lagged and moderation effects found provided 
partial support the second and third (3a, 3c) hypotheses of our study.

\section{Discussion}

The aims of this study were twofold: (1) to perform a broad-band factor-analytic study of dimensionality and construct validity of the Parenting Questionnaire Scales in Portuguese sample of high school students, and (2) to examine the construct validity of the parenting dimensions, with reports of convergent, discriminant and criterion-related validity. The findings are interpreted on the basis of Self-Determination Theory.

The combined results of exploratory and confirmatory factor analyses, along with the lowest AIC estimates obtained for Models $2 \mathrm{mr}$,fr showed that the internal structure of the Parenting Questionnaire Scales is bestrepresented by a solution of 15 -items and 3 factors that distinguish the dimensions of parental need-support, parental psychological control and behavior control.

The improved construct validity of the three-factor solution was further demonstrated at the correlation matrix. As expected, parental need-support and parental psychological control were moderately correlated, signifying that the constructs lie within two distinct motivational continua. In addition, behavior control does not significantly relate to both parental needsupport and psychological control, suggesting that the parental efforts to regulate children's behavior, based on reasonable expectations and adequate monitoring of behavior, are independent of the supportive or thwarting ways through which these efforts are communicated (Soenens \& Vansteenkiste, 2010).

The 3-factor model demonstrated adequate discriminant validity, but further adjustments are necessary to improve the Convergent Validity of some scales. The criterion-related validity of the three factors was also demonstrated. In particular, it was found that the Portuguese high school students experience basic needsatisfaction when they perceive their parents as highly need-supportive (particularly autonomy-supportive) and/or behaviorally controlling, but they do not necessarily experience basic need-frustration when they their parents display psychological control (or psychologically controlling) attitudes. Instead, the perception of parental psychological control, and particularly of maternal psychological control, is related to the experience of low need-satisfaction, whereas neither parental need-support nor behavior control relate to the experience of low need-frustration.

Importantly, the effect of parental psychological control on (low) need-satisfaction was not affected by the degree to which parents are simultaneously perceived as need-supportive and behavior controlling. On the contrary, the positive effects of parental need-support on basic need-satisfaction are significantly buffered by the experience of psychological control.

Finally, we found that parental need-Support and maternal psychological control moderated the positive effect of behavior control on the adolescents' experience of basic need-satisfaction, with parental Need-support amplifying this effect and psychological control buffering it.

Overall, the results indicate that the most optimal pattern of adolescent need-satisfaction is attained when parents combine need-supportive, behavior controlling, and (the lack of) parental psychological control attitudes. Put it in a different way, lower need-satisfaction is experienced when the parents exhibit psychological controlling attitudes, irrespectively on how much need-supportive and behavior controlling they simultaneously are.

One should note, however, that the predictive effects were always stronger, if not only significant, for the maternal data. This particular finding underlines not only the importance of examining the maternal and paternal data separately (for a similar approach, see Barber et al., 1995), but also the need to examine the differential impact of parental and maternal variables in development.

Future studies could examine whether different parenting profiles, resulting from different combinations of the three parental dimensions, predict unique variance on motivational outcomes (e.g., psychosocial identity; Erikson, 1968; Marcia, 1980) and whether this relation is mediated by the experience of basic need-satisfaction and frustration. For instance, it could be examined whether the need-supportive or psychologically controlling behaviors are predominantly triggered by particular emotional states of the parents or by specific features of the child's behavior. To this point, one could hypothesize that parents tend to be mainly need-supportive when they feel more relaxed or when the child displays appropriate behavior, and more psychological controlling when they feel more anxious or when the child is misbehaving (B. Soenens, personal communication, March 3, 2014).

Our research has several limitations. Firstly we conducted a single cross-sectional study based on selfreport measures. This methodology prevented us from drawing firm conclusions about the distinctiveness of the three factors insofar as the differences found may also reflect methodological artifacts, such as the positive or negative way as items are worded. To overcome this problem, future research should combine adolescent and parental self-reports, or use more objective criteria, such as the physiological correlates associated to need-satisfaction and to need-frustration. Additionally, more prospective longitudinal studies should be undertaken to more completely address the way in which these effects develop over time. 
Secondly, in this study we relied on a relatively homogeneous and well-educated sample of Portuguese high school adolescents. Now, the cultural and sampling specificity may not only exemplify two confounding variables to be controlled for, but they can themselves represent alternative explanations for the results. More cross-cultural validation studies are required to exclude the alternative hypothesis that the salience of the associations between the variables reflects the cultural a cultural bias rather than the real nature and dynamics of the constructs.

The use of a normative sample also restricted the variance of our data. In fact, we verified that the scores of parental psychological control were all below the scale mid-point, which, for many authors, indicate the absence of the construct under analysis (e.g., YSI; Young, Klosko, \& Weishaar, 2003). Therefore, we may have not have measured the full experience of psychological control, leaving unchecked the hypothesis that high psychological control scores would have a significant impact on need-frustration. To overcome this limitation, future research should rely on a combination of normative and clinical samples.

Finally, we based our conclusions on a shortened version of the Parenting Questionnaire Scales, and, as we know the findings obtained with shorter scales are less valid than those obtained with longer scales (Smith, McCarthy, \& Anderson, 2000). Therefore it is necessary to cross-validate our findings in independent samples, if we want to generate extended evidence for the psychometric quality and predictive capacity of the 3-factor solution.

This study provided initial validation for the substantive distinction between the need-supportive, psychological control and behaviorally controlling dimensions of parenting, adding new questions on the antecedents, dimensionality and relations between perceived parenting and experienced need-satisfaction and/or frustration in adolescence.

\section{References}

Barber B. K. (1996). Parental psychological control: Revisiting a neglected construct. Child Development, 67, 3296-3319. http://dx.doi.org/10.2307/1131780

Barber B. K. (2002). Intrusive parenting: How psychological control affects children and adolescents. Washington, DC: American Psychological Association Press.

Barber B. K., \& Harmon E. (2002). Violating the self: Parental psychological control of children and adolescents. In B. K. Barber. (Ed.), Intrusive parenting: How psychological control affects children and adolescents. (pp. 15-52). Washington, DC: American Psychological Association Press.

Barber B. K., Olsen J. E., \& Shagle S. C. (1994). Associations between parental psychological and behavioral control and youth internalized and externalized behaviors.
Child Development, 65, 1120-1136. http:/ /dx.doi.org/ 10.2307/1131309

Barber B. K., Stolz H. E., \& Olsen J. A. (1995). Parental support, psychological control, and behavioral control: Assessing relevance across time, culture, and method. Monographs of the Society for Research in Child Development, 70, 1-137.

Barber B. K., \& Xia M. (2013). The centrality of control to parenting and its effects. In A. S. Morris, R. E. Larzelere, \& A. W. Harrist (Eds.), New directions for authoritative parenting (pp. 61-87). Washington, DC: American Psychological Association Press.

Bartholomew K. J., Ntoumanis N., Ryan R. M., \& Thøgersen-Ntoumani C. (2011). Psychological need thwarting in the sport context: Assessing the darker side of athletic experience. Journal of Sport and Exercise Psychology, 33, 75-102.

Baumeister R. F., \& Leary M. R. (1995). The need to belong: Desire for interpersonal attachments as a fundamental human motivation. Psychological Bulletin, 117, 497-529. http: / / dx.doi.org/10.1037 / /0033-2909.117.3.497

Baumrind D. (1966). Effects of authoritative parental control on child behavior. Child Development, 37, 887-907. http:/ / dx.doi.org/10.2307/1126611

Bean R. A., Barber B. K., \& Crane R. D. (2006). Parental support, behavioral control, and psychological control among African American youth: The relationships to academic grades, delinquency, and depression. Journal of Family Issues, 27, 1335-1355. http:/ / dx.doi.org/10.1177/ 0192513X06289649

Byrne B. M. (2010). Structural equation modeling with AMOS (2nd Ed.). New York, NY: Routledge.

Cordeiro P. M., Paixão M. P., Lens W., \& Sheldon K. (2015). The Portuguese adaptation of the Balanced Measure of Psychological Needs Scale: Dimensionality and construct validity. (Manuscript submitted for publication).

Deci E. L., \& Ryan R. M. (1985). Intrinsic motivation and self-determination in human behavior. New York, NY: Plenum.

Deci E. L., \& Ryan R. M. (2000). The "What" and "Why" of goal pursuits: Human needs and the self-determination of behavior. Psychological Inquiry, 11, 227-268. http://dx.doi. org/10.1207/S15327965PLI1104_01

Duriez B., Soenens B., \& Vansteenkiste M. (2007). In search of the antecedents of adolescent authoritarianism: The relative contribution of parental goal promotion and parenting style dimensions. European Journal of Personality, 21, 507-527. http://dx.doi.org/10.1002/ per.623

Erikson E. H. (1968). Identity youth and crisis. New York, NY: Norton.

Fornell C., \& Larcker D. F. (1981). Evaluating structural equation models with unobservable variables and measurement error. Journal of Marketing Research, 18, 39-50. http:/ / dx.doi.org/10.2307/3151312

Gaskin J., (2015), Name of tab. Stats Tools Package. Cleveland, $\mathrm{OH}$ : Case Western Reserve University. Retrieved from http:/ / statwiki.kolobkreations.com

Gray M. R., \& Steinberg L. (1999). Unpacking authoritative parenting: Reassessing a multidimensional construct. 
Journal of Marriage and the Family, 61, 574-587. http:/ /dx. doi.org/10.2307/353561

Grolnick W. S., \& Ryan R. M. (1989). Parent styles associated with children's self-regulation and competence in school. Journal of Educational Psychology, 81, 143-154. http:/ / dx.doi.org/10.1037/ /0022-0663.81.2.143

Grolnick W. S., Ryan R. M., \& Deci E. L. (1991). The inner resources for school achievement: Motivational mediators of children's perceptions of their parents. Journal of Educational Psychology, 83, 508-517. http:/ /dx.doi.org/ 10.1037 / / 0022-0663.83.4.508

Hambleton R. K. (2001). The next generation of the ITC test translation and adaptation guidelines. European Journal of Psychological Assessment, 17, 164-172. http:/ /dx.doi.org/ 10.1027//1015-5759.17.3.164

Hu L. T., \& Bentler P. M. (1999). Cutoff criteria for fit indexes in covariance structure analysis: Conventional criteria versus new alternatives. Structural Equation Modeling, 6, 1-55. http:/ / dx.doi.org/10.1080/10705519909540118

Marcia J. E. (1980). Identity in adolescence. In J. Adelson (Ed.), Explorations in personality: A clinical and experimental study of fifty men of college age (pp. 491-501). New York, NY: Oxford University Press.

Maroco J. (2010). Análise de equações estruturais: fundamentos teóricos, software $\mathcal{E}$ aplicações [Structural Equation Analysis: Theoretical foundations, software and applications]. Lisbon, Portugal: Reportnumber.

McIver J. P., \& Carmines E. G. (1981). Unidimensional scaling. Thousand Oaks, CA: Sage.

Miklikowska M., Duriez B., \& Soenens B. (2011). Family roots of empathy-related characteristics: The role of perceived maternal and paternal need support in adolescence. Developmental Psychology, 47, 1342-1352. http:/ /dx.doi.org/10.1037/a0024726

Ryan R. M. (1995). Psychological needs and the facilitation of integrative processes. Journal of Personality, 63, 397-427. http:/ /dx.doi.org/10.1111/j.1467-6494.1995.tb00501.x

Ryan R. M. (1993). Agency and organization: Intrinsic motivation, autonomy and the self in psychological development. In J. Jacobs (Ed.), Nebraska symposium on motivation. Developmental perspectives on motivation. (Vol. 40, pp. 1-56). Lincoln, NE: University of Nebraska Press.

Ryan R. M., \& Deci E. L. (2002). Overview of selfdetermination theory: An organismic dialectical perspective. In R. M. Ryan \& E. L. Deci (Eds.), Handbook of self-determination research (pp. 3-33). Rochester, NY: The University of Rochester Press.

Ryan R. M., \& Deci E. L. (2000). Self-determination theory and the facilitation of intrinsic motivation, social development, and well-being. American Psychologist, 55, 68-78. http:/ / dx.doi.org/10.1037/ / 0003-066X.55.1.68

Ryan R. M., \& Guardia La, J. G. (2000). What is being optimized? Self-determination theory and basic psychological needs. In S. H. Qualls \& N. Abeles (Eds.), Psychology and the aging revolution: How we adapt to longer life (pp. 145-172). Washington, DC: American Psychological Association.

Schaefer E. S. (1965). Children's reports of parental behavior: An inventory. Child Development, 36, 413-424. http:/ /dx.doi.org/10.2307/1126465
Schunk D. H., \& Zimmerman B. J. (2007). Influencing children's self-efficacy and self-regulation of reading and writing through modeling. Reading and Writing Quarterly, 23, 7-25. http:/ /dx.doi.org/10.1080/10573560600837578

Sheldon K. M., Abad N., \& Hinsch C. (2011). A two process view of Facebook use and relatedness need-satisfaction: Disconnectedness drives use and connectedness rewards it. Journal of Personality and Social Psychology, 100, 766-775.

Sheldon K. M., \& Hilpert J. C. (2012). The balanced measure of psychological needs (BMPN) scale: An alternative domain general measure of need satisfaction. Motivation and Emotion, 36, 439-451. http:/ / dx.doi.org/10.1007/ s11031-012-9279-4

Skinner E. A., Johnson S. J., \& Snyder T. (2005). Six dimensions of parenting: A motivational model. Parenting: Science and Practice, 5, 175-235. http:/ / dx.doi.org/10.1207/ s15327922par0502_3

Smith G. T., McCarthy D. M., \& Anderson K. G. (2000). On the sins of short-form development. Psychological Assessment, 12, 102-111. http:/ /dx.doi.org/10.1037// 1040-3590.12.1.102

Soenens B., \& Beyers W. (2012). The cross-cultural significance of control and autonomy in parentadolescent relationships. Journal of Adolescence, 35, 243-248. http://dx.doi.org/10.1016/j.adolescence. 2012.02.007

Soenens B., Duriez B., Vansteenkiste M., \& Goossens L. (2007). The intergenerational transmission of empathyrelated responding in adolescence: The role of maternal responsiveness. Personality and Social Psychology Bulletin, 33, 299-311.

Soenens B., Luyckx K., Vansteenkiste M., Duriez B., \& Goossens L. (2008). Clarifying the link between perceived parental psychological control and adolescents' depressive feelings: Reciprocal versus unidirectional models of influence. Merrill-Palmer Quarterly, 54, 411-444.

Soenens B., \& Vansteenkiste M. (2010). A theoretical upgrade of the concept of parental psychological control: Proposing new insights on the basis of self-determination theory. Developmental Review, 30, 74-99. http:/ / dx.doi. org/10.1016/j.dr.2009.11.001

Soenens B., Vansteenkiste M., Luyckx K., \& Goossens L. (2006). Parenting and adolescent problem behavior: An integrated model with adolescent self-disclosure and perceived parental knowledge as intervening variables. Developmental Psychology, 42, 305-318. http://dx.doi.org/ 10.1037/0012-1649.42.2.305

Soenens B., Vansteenkiste M., Duriez B., \& Goossens L. (2006). In search of the sources of psychologically controlling parenting: The role of parental separation anxiety and parental maladaptive perfectionism. Journal of Research on Adolescence, 16, 539-559. http:/ / dx.doi. org/10.1111/j.1532-7795.2006.00507.x

Soenens B., Vansteenkiste M., Luyten P., Duriez B., \& Goossens L. (2005). Maladaptive perfectionistic selfrepresentations: The mediational link between psychological control and adjustment. Personality and Individual Differences, 38, 487-498. http:/ /dx.doi. org/10.1016/j.paid.2004.05.008 
Steinberg L. (1990). Autonomy, conflict, and harmony in the family relationship. In S. S. Feldman \& G. R. Elliot (Eds.), At the threshold: The developing adolescent (pp. 255-276).

Cambridge, MA: Harvard University Press.

Steinberg L. (2005). Psychological control: Style or substance? In Changing boundaries of parental authority during adolescence. In W. Damon \& J. Smetana (Eds.),

New directions for child and adolescent development (Vol. 108, pp. 71-78). New York, NY: Wiley.

Tiensley H., \& Tiensley D. J. (1987). Uses of factor analysis in counseling psychology research. Journal of Counseling Psychology, 34, 414-424. http://dx.doi.org/10.1037// 0022-0167.34.4.414

Vansteenkiste M., \& Ryan R. M. (2013). On psychological growth and vulnerability: Basic psychological need satisfaction and need frustration as a unifying principle.
Journal of Psychotherapy Integration. 23, 263-280. http:/ / dx.doi.org/10.1037/a0032359

Verstuyf J., Vansteenkiste M., Soenens B., Boone L., \& Mouratidis A. (2013). Daily ups and downs in women's binge eating symptoms: The role of basic psychological needs, general self-control, and emotional eating. Journal of Social and Clinical Psychology, 32, 335-361.

Young J. E., Klosko J. S., \& Weishaar M. E. (2003). Schema therapy. A practitioner's guide. New York, NY: The Guilford Press.

Wang Q., Pomerantz E. M., \& Chen H. (2007). The role of parents' control in early adolescents' psychological functioning: A longitudinal investigation in the United States and China. Child Development, 78, 1592-1610. http://dx.doi.org/10.1111/j.1467-8624. 2007.01085.x 


\section{Appendix A:}

Parenting Questionnaire Items - English version (PQS)

CPSF01 My father/mother makes me feel better after talking over my worries with him/her

CPSF02 My father/mother has clear expectations for how I should behave in and outside the home

CPSF03 My father/mother asks me questions about how I am behaving outside the home

CPSF04 My father/mother is always trying to change how I feel or think about things

CPSF05 My father/mother listens to my opinion or perspective when I've got a problem

CPSF06 My father/mother smiles at me very often

CPSF07 My father/mother requires that I behave in certain ways

CPSF08 My father/mother reminds me of the rules he/she has set for me

CPSF09 My father/mother changes the subject whenever I have something to say

CPSF10 My father/mother is usually willing to consider things from my point of view

CPSF11 My father/mother is able to make me feel better when I am upset

CPSF12 My father/mother believes that children should not be able to do anything they want

CPSF13 My father/mother watches to make sure I behave appropriately

CPSF14 My father/mother often interrupts me

CPSF15 Whenever possible, my father/mother allows me to choose what to do

CPSF16 My father/mother cheers me up when I am sad

CPSF17 My father/mother wants me to learn to follow rules and regulations in and outside of the home

CPSF18 My father/mother talks to neighbours, parents of my friends, or my teachers about my behaviour

CPSF19 My father/mother blames me for other family members' problems

CPSF20 My father/mother allows me to decide things for myself

CPSF21 My father/mother gives me a lot of care and attention

CPSF22 My father/mother believes parents have the right to set rules and regulations for how children should behave

CPSF23 My father/mother makes efforts to know who my friends are and where I spend my time

CPSF24 My father/mother brings up past mistakes when he/she criticizes me

CPSF25 My father/mother insists upon doing things his/her way

CPSF26 My father/mother believes in showing his/her love for me

CPSF27 My father/mother lets me do anything I want

CPSF28 My father/mother doesn't seem to care whether or not I behave like he/she wants me to do

CPSF29 My father/mother is less friendly with me if I do not see things his/her way

CPSF30 My father/mother isn't sensitive to many of my needs

CPSF31 My father/mother enjoys doing things with me

CPSF32 My father/mother has reasonable expectations for my behaviour

CPSF33 My father/mother is unaware of how I am behaving in or outside the home

CPSF34 My father/mother will avoid looking at me when I have disappointed him/her

CPSF35 My father/mother helps me to choose my own direction in life

CPSF36 My father/mother is very unclear as to what he/she expects of me

CPSF37 My father/mother checks on me (what) in reasonable ways (how) to see if I am behaving like he/she wants me to

CPSF38 If I have hurt his/her feelings, my father/mother stops talking to me until I please him/her again 


\section{Appendix B:}

Parenting Questionnaire Items - Portuguese version

QEPP 01

QEPP 02

QEPP 03

QEPP 04

QEPP 05

QEPP 06

QEPP 07

QEPP 08

QEPP 09

QEPP 10

QEPP 11

QEPP 12

QEPPF 13

QEPPF 14

QEPP 15

QEPP 16

QEPP 17

QEPP 18

QEPP 19

QEPP 20

QEPP 21

QEPP 22

QEPP 23

QEPP 24

QEPP 25

QEPP 26

QEPP 27

QEPP 28

QEPP 29

QEPP 30

QEPP 31

QEPP 32

QEPP 33

QEPP 34

QEPP 35

QEPP 36

QEPP 37

QEPP 38
O meu pai/mãe faz-me sentir melhor depois de conversar com ele/a sobre as minhas preocupações

O meu pai/mãe tem expectativas claras acerca de como me devo comportar dentro e fora de casa

$\mathrm{O}$ meu pai/mãe faz-me perguntas relacionadas com o meu comportamento fora de casa

O meu pai/mãe está sempre a tentar mudar o que eu me sinto ou penso

O meu pai/mãe ouve a minha opinião ou ponto de vista quando tenho um problema

O meu pai/mãe sorri muitas vezes para mim

O meu pai/mãe exige que eu me comporte de uma certa maneira

O meu pai/mãe lembra-me das regras que definiu para mim

O meu pai/mãe muda de assunto sempre que estou a tentar dizer alguma coisa

O meu pai/mãe está geralmente disposto a ver as coisas de acordo com o meu ponto de vista

O meu pai/mãe é capaz de me fazer sentir melhor quando estou chateado(a)

O meu pai/mãe acredita que os jovens não podem fazer tudo o que desejam

O meu pai/mãe está atento ao meu comportamento para se assegurar que é adequado

O meu pai/mãe interrompe-me com frequência

Sempre que lhe é possível, o meu pai/mãe permite-me escolher o que quero fazer

O meu pai/mãe anima-me quando estou triste

O meu pai/mãe quer que eu aprenda a seguir regras e normas, dentro e fora de casa

O meu pai/mãe fala com os vizinhos, pais dos meus amigos e professores sobre o meu comportamento

O meu pai/mãe culpa-me pelos problemas dos outros membros da minha família

O meu pai/mãe permite-me tomar decisões por mim mesmo(a)

O meu pai/mãe cuida de mim e dá-me muita atenção

O meu pai/mãe acredita que os pais têm o direito de definir regras e normas para o comportamento dos jovens

O meu pai/mãe esforça-se para saber quem são meus amigos e onde é que eu passo o meu tempo

Quando me critica, o meu pai/mãe lembra-me os erros que cometi no passado

O meu pai/mãe insiste em fazer as coisas à sua maneira

O meu pai/mãe acredita que deve expressa o amor que sente por mim

O meu pai/mãe deixa-me fazer o que eu quero

O meu pai/mãe parece não se importar se eu me comporto ou não como ele quer

O meu pai/mãe é menos amigável comigo quando eu vejo as coisas de forma diferente da dele/a

O meu pai/mãe não é sensível a muitas das minhas necessidades

O meu pai/mãe gosta de realizar actividades comigo

O meu pai/mãe tem expectativas adequadas para o meu comportamento

O meu pai/mãe não sabe como me comporto dentro ou fora de casa

O meu pai/mãe evita olhar para mim quando o/a decepciono

O meu pai/mãe ajuda-me a escolher o meu caminho na vida

O meu pai/mãe é muito pouco claro relativamente ao que espera de mim

O meu pai/mãe verifica de forma sensata se me estou a comportar como ele/a deseja

Quando firo os sentimentos do meu pai/mãe, ele/a deixa de falar comigo até que me volte a comportar de uma forma que lhe agrade novamente 